University for Business and Technology in Kosovo

UBT Knowledge Center

Nov 2nd, 9:00 AM - Nov 3rd, 5:00 PM

\title{
Seismic Hazard Assessment In Banja HPP Project Area and the Urban Surroundings
}

Megi Rusi

LIM-EM Construction, megirusi@yahoo.com

Follow this and additional works at: https://knowledgecenter.ubt-uni.net/conference

Part of the Architecture Commons

\section{Recommended Citation}

Rusi, Megi, "Seismic Hazard Assessment In Banja HPP Project Area and the Urban Surroundings" (2012). UBT International Conference. 27.

https://knowledgecenter.ubt-uni.net/conference/2012/all-events/27

This Event is brought to you for free and open access by the Publication and Journals at UBT Knowledge Center. It has been accepted for inclusion in UBT International Conference by an authorized administrator of UBT Knowledge Center. For more information, please contact knowledge.center@ubt-uni.net. 


\title{
"SEISMIC HAZARD ASSESMENT IN BANJA HPP PROJECT AREA AND THE URBAN SORROUNDINGS"
}

\author{
Ph.D. Cand. Megi RUSI ${ }^{1}$ \\ ${ }^{1}$ LIM-EM Construction Tirana, Albania, \\ megirusi@yahoo.com
}

\begin{abstract}
The Banjë Hydropower project area, located some $100 \mathrm{~km}$ south of Tirana, includes the middle reaches of Devoll Valley close to the village of Banjë (Elbasan district). HPP "Banja" is the lowermost stage of that will be constructed in Devoll river and it is a middle-head scheme with an annual storage capacity for peaking energy production.

Closely related to the complicated tectonic pattern of the Dinarides-Albanides-Hellenides mountain range, Albania is one of the most tectonically active countries in Europe.

For this purpose an assessment of the seismicity of the project area in general and the dam locations in particular has been made. Risks and hazardsfo the dam itself and the sorrounding urban areas have been determined and measurements have been proposed.
\end{abstract}

The paper at hand is an attempt to clarify the methodods used for conducting this assesments and to clarify the seismic conditions of the project area.

Key Words: Hydro Power, seismicity, environment, urban area. 